\title{
An Appraisal of Land Use/Land Cover Change Scenario of Tummalapalle, Cuddapah Region, India-A Remote Sensing and GIS Perspective
}

\author{
Yenamala Sreedhar ${ }^{1}$, Arveti Nagaraju'1, Gurram Murali Krishna ${ }^{2}$ \\ ${ }^{1}$ Department of Geology, Sri Venkateswara University, Tirupati, India \\ ${ }^{2}$ Xinthe Technologies, Visakhapatnam, India \\ Email: arveti9@gmail.com
}

How to cite this paper: Sreedhar, Y., Nagaraju, A. and Krishna, G.M. (2016) An Appraisal of Land Use/Land Cover Change Scenario of Tummalapalle, Cuddapah Region, India-A Remote Sensing and GIS Perspective. Advances in Remote Sensing, 5, 232-245.

http://dx.doi.org/10.4236/ars.2016.54019

Received: August 30, 2016

Accepted: November 13, 2016

Published: November 16, 2016

Copyright $\odot 2016$ by authors and Scientific Research Publishing Inc. This work is licensed under the Creative Commons Attribution International License (CC BY 4.0).

http://creativecommons.org/licenses/by/4.0/

(c) (i) Open Access

\begin{abstract}
The study was aimed at appraising the changing land use/land cover scenario of Tummalapalle region in Cuddapah district of Andhra Pradesh using Remote sensing data and GIS technology. The region is considered as it has rich uranium reserves and is experiencing a remarkable expansion in recent times. The land use/land cover change analysis was carried out using IRS P6 LISS-III and LANDSAT-8 OLI multitemporal data pertaining to the years 2006 and 2016. The image classification resulted in five major land use/land cover classes namely built-up, agricultural, forest, wasteland and water bodies. The study noticed that the areas under built-up and agricultural classes are found increased from $0.94 \mathrm{~km}^{2}(0.84 \%)$ to $2.75 \mathrm{~km}^{2}(2.44 \%)$ and $61.68 \mathrm{~km}^{2}(54.84 \%)$ to $63.91 \mathrm{~km}^{2}$ (56.82\%), respectively during 2006-2016. Area under forest, wasteland and water bodies are found decreased considerably from 3.09 $\mathrm{km}^{2}(2.75 \%)$ to $0.86 \mathrm{~km}^{2}$ (0.76\%), $43.71 \mathrm{~km}^{2}(38.56 \%)$ to $42.60 \mathrm{~km}^{2}$ (37.88\%) and 3.05 $\mathrm{km}^{2}(2.71 \%)$ to $2.35 \mathrm{~km}^{2}$ (2.09\%), respectively. The study recommends development of industrial based economy by optimally utilizing the existing land resource (scrub and wasteland classes) and simultaneously extending the agricultural practices to other possible areas to make them more productive.
\end{abstract}

\section{Keywords}

Remote Sensing and GIS, Image Classification, Land Use/Land Cover, Tummalapalle

\section{Introduction}

The land use/land cover pattern of any region is an outcome of various physical, cultural factors and their utilization by man in time and space. In general, the term "land use" refers to the human activity or economical functions associated with a specific 
geography. Lillesand and Kiefer [1] described the land cover as a type of natural features present on the surface of the earth. It is widely recognized that study of land use/land cover change (LU/LC) phenomena at local, regional, and global levels is crucial for understanding the negative impacts on environment, which include impact on climate, water resource, soil, ecosystem, human health, safety etc. [2]-[13]. Therefore, the proper understanding of the influence of the various human induced land use practices with regard to the environmental change essentials as it helps to simulate the changes [14]. The knowledge is also essential for deriving an appropriate developmental plan which also addresses the impeding issues like uncontrolled development, deteriorating environmental quality, loss of prime agricultural lands, destruction of important wetlands and loss of natural habitats etc. On the other hand, in order to use the land resource optimally, it is vital to have the information on existing land use/land cover as well as the capability to monitor the dynamics of land use resulting out of changing demands of increasing population [15]-[20]. The underlying causes are complex as they originate from a highly diversified variables such as social, political, economic, demographic, technological, cultural, and biophysical which evolve from human and environment interactions and are structural (or systemic) in nature [21] [22] [23].

Remote sensing technology is considered most effective as it provides timely and authentic information about the spatial distribution of land use/land cover, while Geographical information System (GIS) provides a flexible digital environment for collecting, storing, visualising and analyzing the spatial data [24]. Remote sensing as a vital tool helps for rapid assessment and monitoring of natural resource. When combined with GIS, it makes it possible to map land use/cover phenomena in detailed for further planning, development and decision making, which is essential for meeting the increasing demands and welfare of ever growing population [25] [26] [27] [28].

The rich uranium reserves and mining activity of Tummalapalle experience a remarkable expansion in recent times. Hence, an attempt is made to analyze the existing land use/land cover pattern, temporal dynamics and its impact on the environment of the region.

\section{Study Area}

Tummalapalle is located in Vemula Mandal of Cuddapah district of Andhra Pradesh. It is situated between the Northern latitudes of $14^{\circ} 16^{\prime} 30^{\prime \prime}$ to $14^{\circ} 24^{\prime} 0^{\prime \prime}$ and Eastern longitudes of $78^{\circ} 13^{\prime} 30^{\prime \prime}$ to $78^{\circ} 22^{\prime} 30^{\prime \prime}$ with an area of $112.48 \mathrm{~km}^{2}$ (Figure 1 ). The entire area is covered by Survey of India 1:50,000 scale topographic map numbered 57J/7. Geologically the area is characterized by Papaghni and Chitravati group of rocks belongs to Cuddapah Super Group. The radioactive minerals identified in the ore zone are pitchblende, coffinite, U-Ti complex [29] [30]. The climate of the region is categorised as semi-arid, experiences a minimum temperature of $25^{\circ} \mathrm{C}$ during winter (DecemberJanuary) and a maximum of $32^{\circ} \mathrm{C}$ to $43^{\circ} \mathrm{C}$ during summer (April-May). The average rainfall is of the order of $700-760 \mathrm{~mm}$ /year. June to September is the rainy month which receives a maximum due to South-West monsoon. The area also receives rainfall 
due to North-East monsoon during November-December.

\section{Materials and Methods}

\subsection{Data Used}

Multi-temporal image acquired by LISS-III sensor of IRS-P6, ResourceSat-1 of $23.5 \mathrm{~m}$ resolution and LANDSAT-8's Operational Land Imager sensor data of $30 \mathrm{~m}$ resolution was used for the study. The details of satellites, sensors and spatial resolutions are mentioned in Table 1.

\subsection{Methodology}

The process of geodata creation and analysis involves various digital image processing techniques such as, data preparation, georeferencing, image enhancement, classification, data interpretation, delineation etc. Description of the methodology adopted for the study is provided in the following sections.

- A set of multi-temporal satellite images were collected and processed to show the aerial extent of seasonal crop mapping such as Rabi, Kharif and Zaid from 2006 up to 2016.

- Topographic map with number $57 \mathrm{~J} / 7$ of 1:50,000 scale is used as the base reference layer for field verifications as well as for georeferencing of the satellite image.

- Ground truth data was collected for pre-determined locations carefully determined

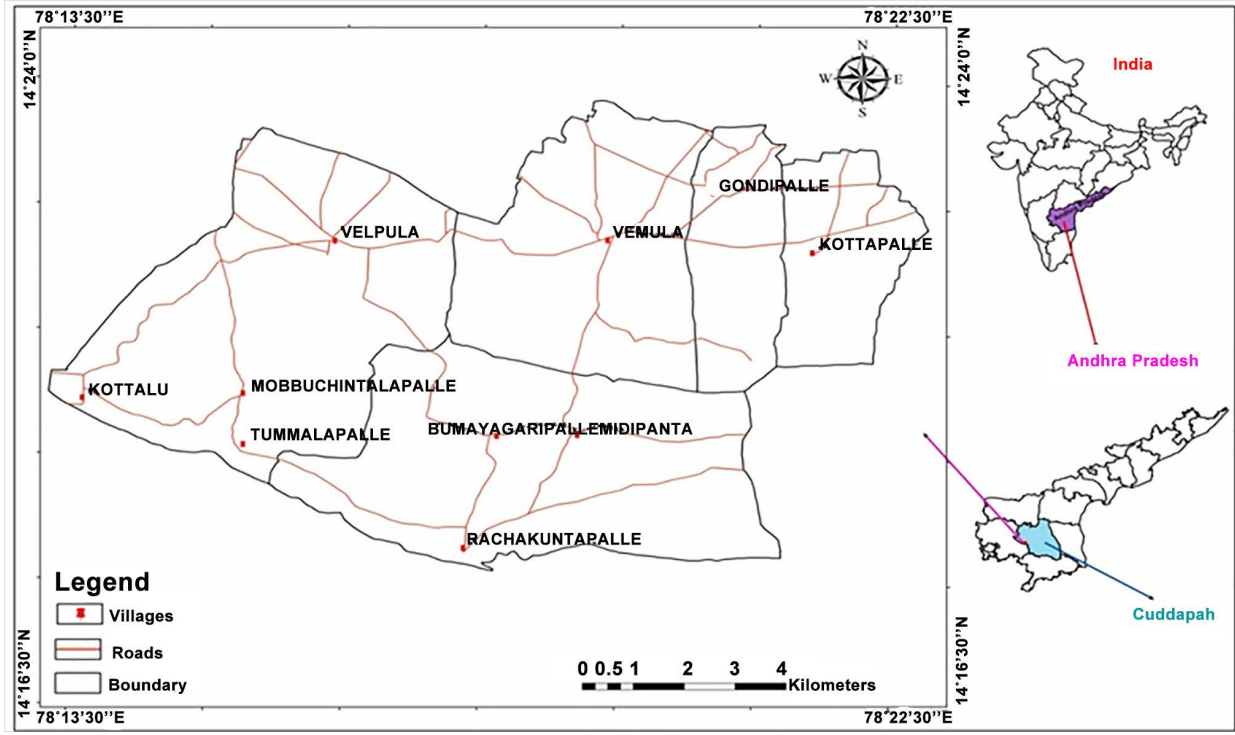

Figure 1. Location map of the study area.

Table 1. Details of the satellite images.

\begin{tabular}{cccc}
\hline S. No. & Date of acquisition & Path-row, scanner, data type & Spatial resolution (m) \\
\hline 1 & 15-May-2006 & 100-63, IRS-P6-LISS III, Multi-spectral & 23.5 \\
2 & 30-Apr-2016 & 143-50, LANDSAT-8 OLI, Multi-spectral & 30.0 \\
\hline
\end{tabular}


from the sample grid generated for the study. The ground truth data was used to determine the authenticity of the image classification results obtained statistically.

- The images data was georeferenced using WGS84 geographical projection system. Standard radiometric and spectral enhancement techniques (cubic convolution) are applied to enhance the interpretability of the image.

- A three level classification schema recommended by NRSC, Govt. of India was adopted for the data classification at different levels. The schema aggregates various land use/land cover features into broad categories such as, Built-up, Transportation, Water bodies, Agricultural and Natural.

- Creation of digital database pertaining to the land use/land cover phenomena through online digitization process involves identification and delineation of feature class as polygon geometry through onscreen digitization using different graphical symbols and color patterns. The follow-up GIS process involves integration of land use/ land cover phenomena into basic topographic layers.

- Multi-temporal land use/land cover maps were generated using the data created using the visual interpretation and onscreen digitization techniques principally based on the image properties like shape, size, pattern, association, tone and textural variations.

- Post field verification was conducted to verify the certainty of the classification results, by establishing the relationship between image elements and tentatively identified land use/land cover categories through visual interpretation.

Land use/land cover change analysis was performed to identify the scale and magnitude of changes occurred in the study area. The results were incorporated into accuracy matrix which helps validating the percent accuracy of the results obtained. The methodology flow implemented for the study is represented schematically as a flow chart (Figure 2).

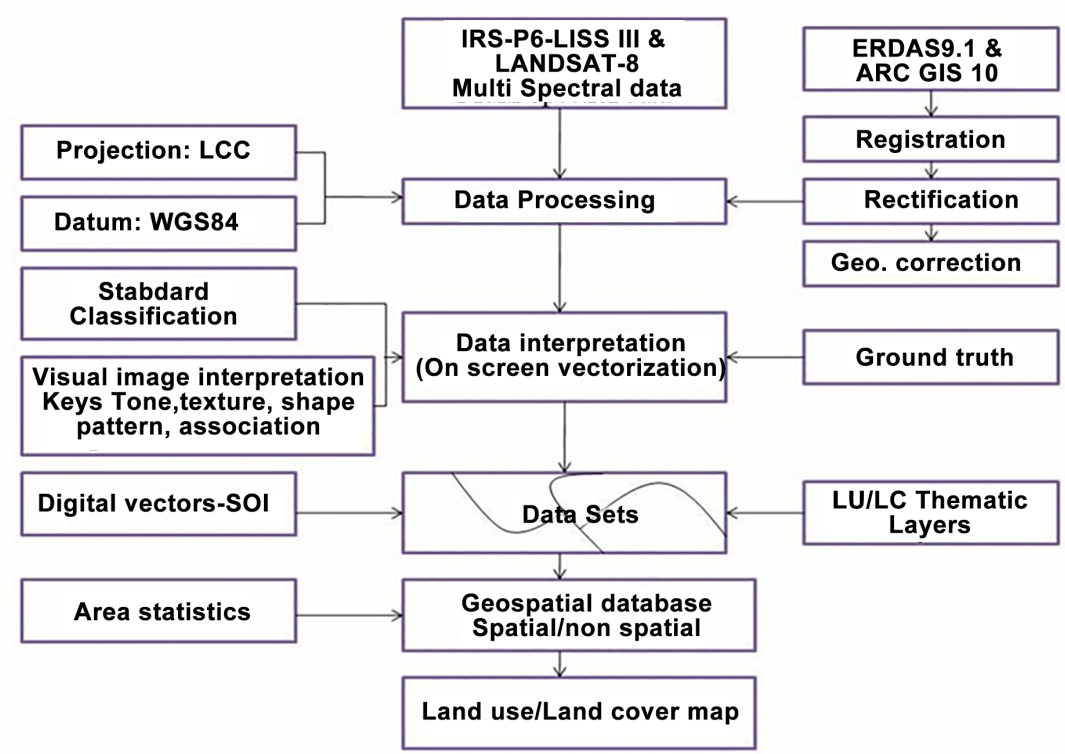

Figure 2. Schematic representation of the process flow of land use/land cover change analysis. 


\subsection{Land Use/Land Cover Classification}

Georeferenced and rectified image were classified according to the schema specified by NRSC, 2006 [31]. Various land use/land cover categories have been enlisted in a hierarchical form of 3 levels. The first level contains broad land use/land cover category such as built-up land, agricultural land, plantation, forest, water bodies and waste lands (un-utilized land) which can be delineated using a satellite image of coarser resolution on 1:50,000 scale with minimal assistance from supplemental information. Such information is useful for general planning purposes at regional level. Land use/land cover categories in level-II and level-III will further breakdown to deeper levels in terms of the feature details, which is only possible using high resolution satellite imagery at map scales 1:10,000 and 1:5000 or less, respectively. With the support of ground truth information, visual interpretation techniques have been used to classify the land use/land cover phenomena which take into consideration various image properties such as, size, shape, color, tone, texture, association and pattern.

\section{Results}

The various land use/land cover categories identified, delineated and mapped (Figure 3) through image classification techniques are enlisted and presented along with their areas and percentages in Table 2. The broad categories thus mapped such as built-up, agricultural, forest, water bodies and wastelands are discussed in detailed in the following sections.

The review of classified Landsat- 8 image of 2016 scenario highlights that majority of the area $(54.8 \%)$ is still under agricultural land which include kharif $\left(26.44 \mathrm{~km}^{2}\right)$, rabi $\left(14.11 \mathrm{~km}^{2}\right)$, double crop $\left(1.55 \mathrm{~km}^{2}\right)$ and current fallow $\left(19.53 \mathrm{~km}^{2}\right)$ followed by scrub land (36.3\%) which include both dense $\left(27.63 \mathrm{~km}^{2}\right)$ and open $\left(13.19 \mathrm{~km}^{2}\right)$.

\subsection{Built-Up (Rural)}

Interpretation of satellite images reveals island like areas of smaller size having population less than 5000, mainly associated with non-commercial and agricultural activities and with allied classes are identified as built up (rural) category. All the built up land increases gradually towards mining site indicates that there is a significant expansion in the mining industry and it amplifies its development during period of study. The population of the study area includes the inhabitants of settlements with a high proportion and their additional demands of daily commuters and workers of the mining sector encompasses economic success and human development. These underpinned developments might change rapidly in the future. Proper evaluation and consideration of the growth rate and its implication on environment should be assessed more precisely for the sustainable development of the study area.

Most of these built-up areas are the combination of residential, commercial, transportation (roads) etc. classes and meant for the habitation of the population [32] [33]. These areas are appeared in dark bluish-green tone in the core and bluish in the periphery. The size of these areas are found to vary between small to big with irregular and 


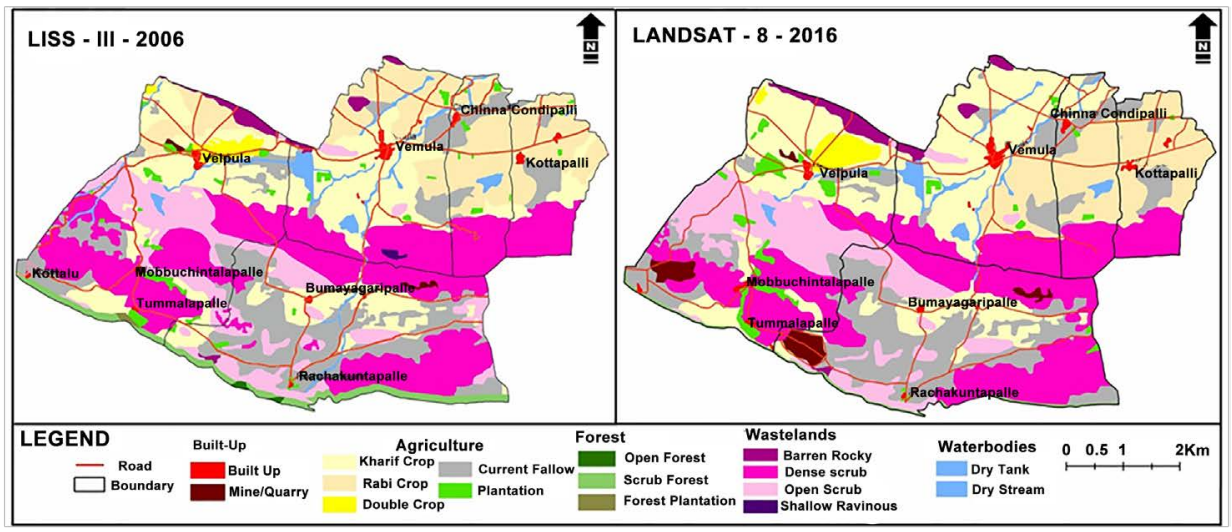

Figure 3. The land use/land cover categories mapped in the study area in 2006 and 2016.

Table 2. Different land use/land cover classes, their area and percentage distribution.

\begin{tabular}{ccccccc}
\hline \multirow{2}{*}{ LU/LC Category } & \multicolumn{2}{c}{2006} & \multicolumn{2}{c}{2016} & \multicolumn{2}{c}{ Change 2006-16 } \\
\cline { 2 - 7 } & Area $\left(\mathrm{km}^{2}\right)$ & \% to TGA & Area $\left(\mathrm{km}^{2}\right)$ & \% to TGA & Area $\left(\mathrm{km}^{2}\right)$ & \% to TGA \\
\hline Built Up & 0.73 & 0.65 & 0.95 & 0.84 & 0.22 & 0.19 \\
Mine/Quarry & 0.21 & 0.19 & 1.8 & 1.60 & 1.59 & 1.41 \\
Kharif Crop & 22.85 & 20.31 & 26.44 & 23.51 & 3.59 & 3.20 \\
Rabi Crop & 17.65 & 15.69 & 14.11 & 12.55 & -3.54 & -3.14 \\
Double Crop & 1.09 & 0.97 & 1.55 & 1.38 & 0.46 & 0.41 \\
Current Fallow & 18.43 & 16.38 & 19.53 & 17.36 & 1.1 & 0.98 \\
Plantation & 1.67 & 1.49 & 2.29 & 2.04 & 0.62 & 0.55 \\
Open Forest & 0.13 & 0.12 & 0.00 & 0.00 & -0.13 & -0.12 \\
Scrub Forest & 2.86 & 2.54 & 0.86 & 0.76 & -2.00 & -1.78 \\
Forest Plantation & 0.10 & 0.09 & 0.00 & 0.00 & -0.1 & -0.09 \\
Barren Rocky & 1.15 & 1.02 & 1.78 & 1.58 & 0.63 & 0.56 \\
Dense Scrub & 30.53 & 27.14 & 27.63 & 24.57 & -2.9 & -2.57 \\
Open scrub & 11.89 & 10.57 & 13.19 & 11.73 & 1.3 & 1.16 \\
Shallow Ravenous & 0.14 & 0.13 & 0.00 & 0.00 & -0.14 & -0.13 \\
Dry Tank & 1.16 & 1.03 & 1.32 & 1.17 & 0.16 & 0.14 \\
Dry Stream & 1.89 & 1.68 & 1.03 & 0.92 & -0.86 & -0.76 \\
Total & 112.48 & 100 & 112.48 & 100 & & \\
\hline
\end{tabular}

$\%$ of TGA $=$ Percentage of Total Geographical Area.

discontinuous pattern. Change analysis revealed that the area under built-up (rural) is increased from $0.94 \mathrm{~km}^{2}(0.84 \%)$ to $2.75 \mathrm{~km}^{2}(2.44 \%)$ indicating an overall increase of $1.81 \mathrm{~km}^{2}(1.6 \%)$ in the area.

\subsection{Agricultural Land}

The land use category primarily used for the production of food and fiber [34] and is the function of land utilization for agricultural productivity over a period of time. The 
category includes both cultivated (single crop) and irrigated (double crop). From the image the agricultural fields are discerned with the chief indication of distinctive geometry (cadastral bounds) associated with agriculture activity and traces produced by livestock equipment. In a false color image, agricultural areas appear bright red to red in color with tessellation mostly with rectangular shape and varying size in contiguous pattern. Kharif (August-November), Rabi (January-March), zaid rabi crops (AprilMay) are the three cropping seasons usually found in the study area as in the places elsewhere in India. Agricultural class is found as the major category covering $61.68 \mathrm{~km}^{2}$ (54.84\%) in 2006 and increased to $63.91 \mathrm{~km}^{2}$ (56.82\%) in 2016. The extent of change is accounted as $5.77 \mathrm{~km}^{2}$ which is $5.14 \%$ of the total area. Most of the agricultural land in the study area is being used for growing both kharif and rabi crops. Alternatively during the summer season it is left vacant (current fallow). Interpretation of both the images pertaining to 2006 and 2016 reveals that there is no significant change in area under the agricultural class.

\subsubsection{Kharif Area}

Agricultural area cultivated during monsoon season (August-November) is considered as kharif. The areas appear bright red to red color on image and prominently found with irrigation facilities. Kharif is found to be the major agricultural category with an extension of $22.85 \mathrm{~km}^{2}$ (20.31\%), which has been increased to $26.44 \mathrm{~km}^{2}(23.51 \%)$ in 2016. The increase in the area i.e., $3.59 \mathrm{~km}^{2}$ is accounted for $3.20 \%$ of the total study area.

\subsubsection{Rabi Area}

Rabi season usually extends from November-March but unlike kharif the areas may be with are without irrigation source. Similar to kharif, rabi crop is also interpreted based on its bright red to red color. This is the second major agricultural land category mapped in the study area. However the extent in rabi was noticed a decrease from $17.65 \mathrm{~km}^{2}$ (15.69\%) in 2006 to $14.11 \mathrm{~km}^{2}(12.55 \%)$ in 2016 , which accounts for $-3.54 \mathrm{~km}^{2}(-3.14 \%)$ of the total study area.

\subsubsection{Double Crop Area}

Double crop areas are noticed both in kharif and rabi seasons. The areas are found with $1.09 \mathrm{~km}^{2}(0.97 \%)$ in 2006 and increased to $1.55 \mathrm{~km}^{2}(1.38 \%)$ in 2016 . The increase in the area accounts for $0.46 \mathrm{~km}^{2}(0.41 \%)$ of the total study area.

\subsection{Current Fallow}

The agricultural land which is being used for cultivation but is temporarily allowed to rest or un-cropped for one or more seasons, but not less than a year is referred to as current fallow [35]. In the image current fallow is found devoid of crops both in kharif and rabi seasons. They appeared in yellow to dark greenish blue tone with varying rectangular shapes and sizes. Current fallow is found increased from $18.43 \mathrm{~km}^{2}(16.38 \%)$ in 2006 to $19.53 \mathrm{~km}^{2}(17.36 \%)$ in 2016 , which accounts for a change of $1.1 \mathrm{~km}^{2}(0.98 \%)$ of the total area. 


\subsection{Plantation}

Plantation can be described as an agricultural area with trees planted adopting certain agricultural management techniques. Plantation appear in dark-red to red tone of different sizes with regular and sharp edges indicating the presence of a fence around it. Depending on the location, they exhibit a dispersed or contiguous pattern and may depend on the lithology. Plantation is found increased from $1.67 \mathrm{~km}^{2}(1.49 \%)$ in 2006 to $2.29 \mathrm{~km}^{2}(2.04 \%)$ in 2016 , which accounts for a change $0.62 \mathrm{~km}^{2}(0.55 \%)$ of the total area.

\subsection{Forest}

Anderson [36] describes the forest as the areas bearing an association predominantly of trees and other vegetation types capable of producing timber and other forest products and exerts an influence on the climate and water regime. Forest areas are found within the notified boundaries as marked in the Survey of India toposheets. The areas are easily identified on imagery with bright red to dark red tone. Forest areas are found manifested with different sub-categories such as open forest, scrub forest, forest plantation which are explained in detail below. It is noticed that open forest has lost $0.13 \mathrm{~km}^{2}$ of area during 2006-2016 which accounts for $0.12 \%$ of total area. The change in the loss of forest area is mainly due to mining activities in the region.

\subsubsection{Open Forest}

Open forest is a mixture of trees and scrubs where the tree species are less in nature and can be identified with pink to dark in tone in the image. Open forest is found decreased by $0.13 \mathrm{~km}^{2}(0.12 \%)$ during $2006-2016$.

\subsubsection{Scrub Forest}

Scrub forest is typically manifested with extensively grown scrubs. Scrub forest appeared with light red to dark brown in the image depending on the canopy cover and soil background. The size is found varying from small to big, irregular to discontinuous in shape, contiguous to non-contiguous in appearance. These areas are found on hill slopes within notified forest areas, at times closer to habitations. Area under this category is decreased from $2.86 \mathrm{~km}^{2}(2.54 \%)$ in 2006 to $0.86 \mathrm{~km}^{2}(0.76 \%)$ in 2016 which accounts for $-2.00 \mathrm{~km}^{2}(1.78 \%)$ of the total study area.

\subsubsection{Forest Plantation}

The category has tree species of forestry importance (like Teak, Sal, Eucalyptus, Casurina, Bamboo etc.) raised and managed especially in notified forest areas. They appear in light red to red color of varying sizes mostly in contiguous pattern and at times noncontiguous. The category is decreased from $0.10 \mathrm{~km}^{2}$ to $0.09 \%$ during 2006-2016, which accounts for $-0.1 \mathrm{~km}^{2}(-0.09 \%)$ of the total study area.

\subsection{Wastelands}

The degraded and under-utilized land could be brought under productive use with 
proper soil and water management practices [37] [38]. Wastelands may result from various environmental and human factors. The various wasteland categories mapped at level II and level III in the study area are as follows.

\subsubsection{Barren Rocky Areas}

The barren rock exposures are especially confined to hilly terrain with down slope with rock outcrops, stony waste and fragments. Depending on the rock type, they appear greenish blue to yellowish color on image. The area under this category is increased from $1.15 \mathrm{~km}^{2}(1.02 \%)$ in 2006 to $1.78 \mathrm{~km}^{2}(1.58 \%)$ in 2016 which accounts for $0.63 \mathrm{~km}^{2}$ $(0.56 \%)$ of the total area.

\subsubsection{Scrub Land}

Scrub is usually confined to topographically elevated areas, on the hill slopes generally surrounded by agricultural lands [39]. Scrub is demarcated by its light yellow to brown to greenish blue color in image which may vary depending on the surface moisture. It is found with varying sizes of small to large areas having contiguous or dispersed pattern. Dense scrub is mostly identified on the hills and found decreased from $30.53 \mathrm{~km}^{2}$ (27.14\%) in 2006 to $27.63 \mathrm{~km}^{2}$ (24.57\%) in 2016 which accounts for $-2.9 \mathrm{~km}^{2}(-2.57 \%)$ of the total study area. Open scrub is found foothills surrounded by agricultural lands found increased from $11.89 \mathrm{~km}^{2}$ (10.57\%) in 2006 to $13.19 \mathrm{~km}^{2}$ (11.73\%) in 2016 which accounts for $1.3 \mathrm{~km}^{2}(1.16 \%)$ of the total study area.

\subsection{Ravenous Land}

Ravenous land is the result of the action of surface runoff on unconsolidated rock/soil terrain. They appear in light yellow to bluish green in tone depending on the depth of erosion and exposure of parent material. Ravenous category is found having $0.14 \mathrm{~km}^{2}$ $(0.13 \%)$ in 2006 to nil in 2016 which accounts for a decrease of $-0.14 \mathrm{~km}^{2}(-0.13 \%)$ of the total study area.

\subsection{Waterbodies}

Waterbodies include running waterbodies (streams, rivers etc.) and lakes/tanks/reservoirs which may be natural or man-made. Waterbodies are easily identified from the image as they appear light blue to dark blue or cyan color depending on the depth of the water. Streams (dry streams) are found having an area of $1.89 \mathrm{~km}^{2}(1.68 \%)$ in 2006 and slightly decreased to $1.03 \mathrm{~km}^{2}(0.92 \%)$ in 2016 , which accounts for $-0.86 \mathrm{~km}^{2}(0.76 \%)$ of the total study area. While lakes/tanks/reservoirs (mostly dry) are found slightly increased from $1.16 \mathrm{~km}^{2}(1.03 \%)$ in 2006 to $1.32 \mathrm{~km}^{2}(1.17 \%)$ in 2016, which accounts for $0.16 \mathrm{~km}^{2}$ $(0.14 \%)$ of the total area.

\section{Discussion}

The extent of the change in land use/land cover phenomena is represented using a graph (Figure 4) which indicates the change occurred in each category during 2006-2016.

It is noticed that the agricultural land is the major land use/land cover category 
which include various sub-categories such as kharif (increased by $3.59 \mathrm{~km}^{2}$ or $3.20 \%$ ), rabi (decreased by $-3.54 \mathrm{~km}^{2}$ or $-3.14 \%$ ), double crop (increased by $0.46 \mathrm{~km}^{2}$ or $0.41 \%$ ), current fallow (increased by $1.1 \mathrm{~km}^{2}$ or $0.98 \%$ ), agriculture plantation (increased by 0.62 $\mathrm{km}^{2}$ or $0.55 \%$ ), followed by the next single major category i.e., dense scrub (decreased by $-2.9 \mathrm{~km}^{2}$ or $-2.57 \%$ ). The other important categories are open scrub (increased by $1.3 \mathrm{~km}^{2}$ or $1.16 \%$ ), scrub forest (decreased by $-2.00 \mathrm{~km}^{2}$ or $-1.78 \%$ ), dry stream (decreased by $-0.86 \mathrm{~km}^{2}$ or $-0.76 \%$ ), dry tanks (increased by $0.16 \mathrm{~km}^{2}$ or $0.14 \%$ ), barren rocky (increased by $0.63 \mathrm{~km}^{2}$ or $0.56 \%$ ), built-up rural (increased by $0.22 \mathrm{~km}^{2}$ or $0.19 \%$ ), industrial/mine/quarry (increased by $1.59 \mathrm{~km}^{2}$ or $1.41 \%$ ), open forest (decreased by -0.13 $\mathrm{km}^{2}$ or $-0.12 \%$ ), forest plantation (decreased by $-0.1 \mathrm{~km}^{2}$ or $-0.09 \%$ ), shallow ravenous (decreased by $-0.14 \mathrm{~km}^{2}$ or $-0.13 \%$ ) (Figure 5 ).

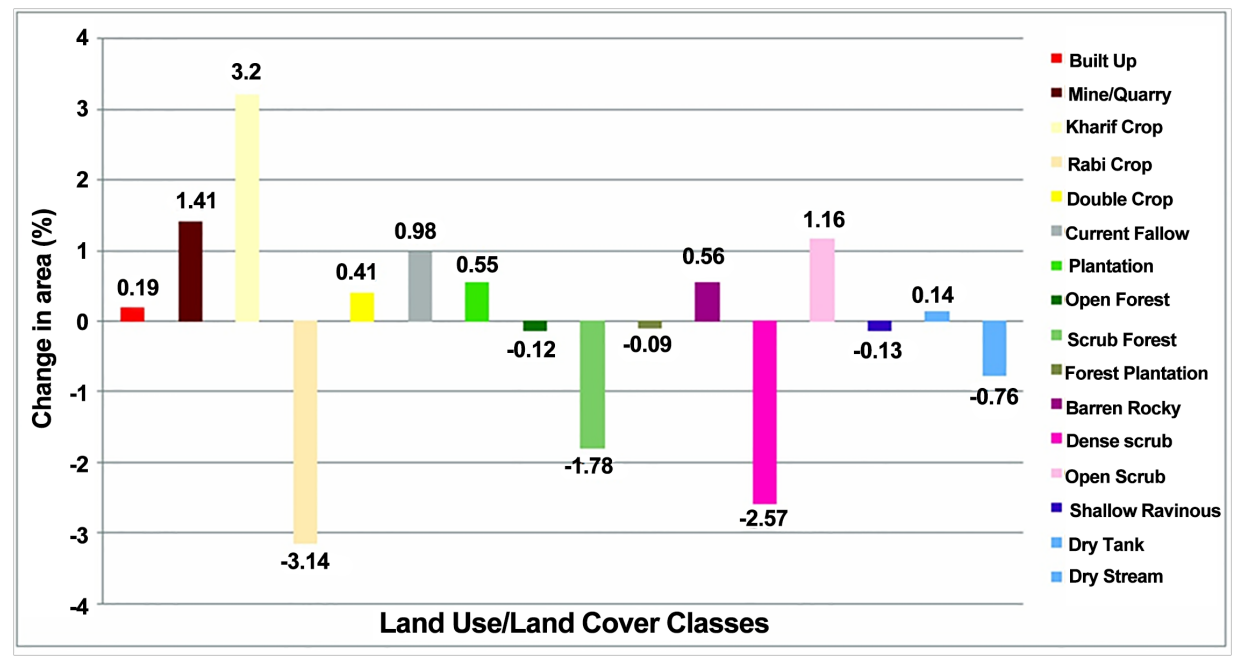

Figure 4. Graph showing the change in extent of land use/land cover categories in 2006-2016.

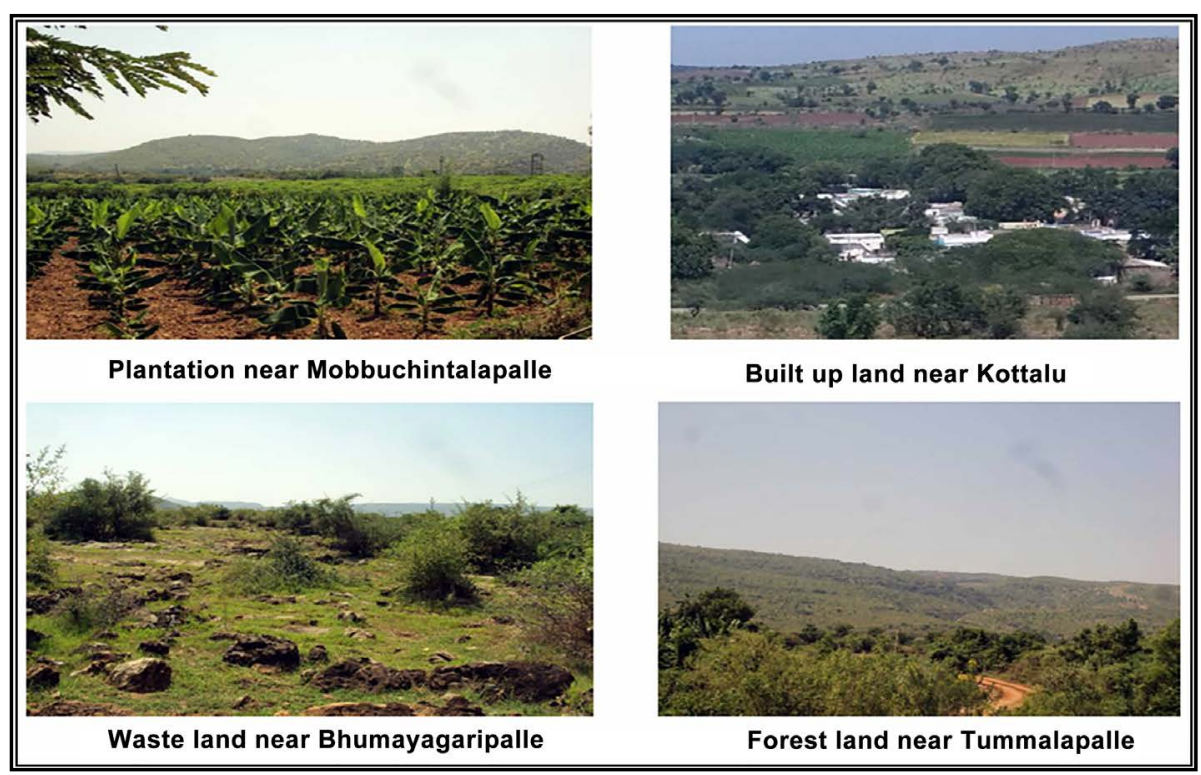

Figure 5. This figure shows the field photos of land use/land cover category. 
It is noticed that there is a significant increase in area (1.41\%) under mining due to the availability of uranium reserves in the study area. However, it is important to development industry based on the availability of mineral resource that would certainly benefit the local economy. The increase $(0.19 \%)$ in built-up class which includes the sub-classes like, residential, commercial transportation etc. can be attributed to the growth in population as well as migration. It is noticed that the built-up class has registered an annual growth rate of $0.019 \%$ and is expected that the growth likely increase further due to rapid growth of population. This necessitates more focused approach by the local bodies for the provision of necessary infrastructure and living amenities, so that the growth would be sustainable.

\section{Conclusion}

The present study aimed at mapping and detecting the land use/land cover change during 2006-2016 in the Tummalapalle region by effectively employing the Remote Sensing and GIS technology. Kharif (agricultural), mining and scrub are the three major land use/land cover categories noticed a major change in terms of their increase during 2006-2016 with 3.2\%, 1.41\% and $1.16 \%$ respectively. On the other hand, rabi (agricultural), dense scrub and scrub forest are the land use/land cover categories witnessed a major change in terms of decrease in their extent i.e., $-3.14 \%,-2.57 \%$ and $-1.78 \%$, respectively. The study has indicated that there is a lot of scope for further development of the study area as most of the areas covered by the land use/land cover categories are un-utilized or un-productive like dense scrub, open scrub, wasteland etc. In addition to this, it is also important to bring mineral based industrial units as the location is rich of uranium and other mineral resources, which also helps in well balanced economic development along with the existing agricultural based economy.

\section{References}

[1] Lillesand, T.M. and Kiefer, R.W. (2000) Remote Sensing and Image Interpretation. IV Edition, John Wiley and Sons, Inc., USA.

[2] Chase, T.N., Pielke, R.A. and Kittel, T.G.F. (2000) Simulated Impacts of Historical Land Cover Changes on Global Climate in Northern Winter. Climate Dynamics, 16, 93-105. http://dx.doi.org/10.1007/s003820050007

[3] Pielke, R.A., Marland, Sr., G., Betts, R.A., Chase, T.N., Eastman, J.L., Niles, J.O., Niyogi, D. and Running, S.W. (2002) The Influence of Land-Use Change and Landscape Dynamics on the Climate System: Relevance to Climate-Change Policy beyond the Radiative Effect of Greenhouse Gases. Philosophical Transactions of the Royal Society A: Mathematical, Physical and Engineering Sciences, 360, 1705-1719. http://dx.doi.org/10.1098/rsta.2002.1027

[4] Pielke, R.A. (2005) Land Use and Climate Change. Science, 310, 1625-1626. http://dx.doi.org/10.1126/science.1120529

[5] Zhang, J.T., Ru, W.M. and Li, B. (2006) Relationships between Vegetation and Climate on the Loess Plateau in China. Folia Geobotanica, 41, 151-163. http://dx.doi.org/10.1007/BF02806476

[6] Findell, K.L., Shevliakova, E., Milly, P.C.D. and Stouffer, R.J. (2007) Modeled Impact of Anthropogenic Land Cover Change on Climate. Journal of Climate, 20, 3621-3634. 
http://dx.doi.org/10.1175/JCLI4185.1

[7] Mahmood, R., Pielke, R.A. Sr., Hubbard, G.K., Niyogi, D., Bonan, G., Lawrence, P., Mcnider, R., Mcalpine, C., Etter, A. and Gameda, S. (2010) Impacts of Land Use/Land Cover Change on Climate and Future Research Priorities. Bulletin of the American Meteorological Society, 91, 37-46. http://dx.doi.org/10.1175/2009BAMS2769.1

[8] Chen, G.S., Notaro, M., Liu, Z. and Liu, Y. (2012) Simulated Local and Remote Biophysical Effects of Afforestation over the Southeast United States in Boreal Summer. Journal of Climate, 25, 4511-4522. http://dx.doi.org/10.1175/JCLI-D-11-00317.1

[9] Ding, H.Y. and Shi, W.Z. (2013) Land-Use/Land-Cover Change and Its Influence on Surface Temperature: A Case Study in Beijing City. International Journal of Remote Sensing, 34, 5503-5517. http://dx.doi.org/10.1080/01431161.2013.792966

[10] Woldemichael, A.T., Hossain, F. and Pielke R.Sr. (2014) Impacts of Postdam Land Use/ Land Cover Changes on Modification of Extreme Precipitation in Contrasting Hydroclimate and Terrain Features. Journal of Hydrometeorology, 15, 777-800.

http://dx.doi.org/10.1175/JHM-D-13-085.1

[11] Yao, X., Wang, Z. and Wang, H. (2015) Impact of Urbanization and Land-Use Change on Surface Climate in Middle and Lower Reaches of the Yangtze River, 1988-2008. Advances in Meteorology, 2015, Article ID: 395094, 10 p.

[12] Fan, X., Ma, Z., Yang, Q., Han, Y., Mahmood, R. and Zheng, Z. (2015) Land Use/Land Cover Changes and Regional Climate over the Loess Plateau during 2001-2009. Part I: Observational Evidence. Climatic Change, 129, 427-440.

http://dx.doi.org/10.1007/s10584-014-1069-4

[13] Fan, X., Ma, Z., Yang, Q., Han, Y. and Mahmood, R. (2015) Land Use/Land Cover Changes and Regional Climate over the Loess Plateau during 2001-2009. Part II: Interrelationship from Observations. Climatic Change, 129, 441-455. http://dx.doi.org/10.1007/s10584-014-1068-5

[14] Prakasam, C. (2010) Land Use and Land Cover Change Detection through Remote Sensing Approach: A Case Study of Kodaikanal Taluk, Tamil Nadu. International Journal of Geomatics and Geosciences, 1, 46-55.

[15] Rawat, J.S., Biswas, V. and Kumar, M. (2013) Changes in Land Use/Cover Using Geospatial Techniques: A Case Study of Ramnagar Town Area, District Nainital, Uttarakhand, India. The Egyptian Journal of Remote Sensing and Space Sciences, 16, 111-117. http://dx.doi.org/10.1016/j.ejrs.2013.04.002

[16] Alqurashi, A.F. and Kumar, L. (2014) Land Use and Land Cover Change Detection in the Saudi Arabian Desert Cities of Makkah and Al-Taif Using Satellite Data. Advances in Remote Sensing, 3, 106-119. http://dx.doi.org/10.4236/ars.2014.33009

[17] Sreenivasulu, G., Jayaraju, N., Kishore, K. and Lakshmi Prasad, T. (2014) Landuse and Landcover Analysis Using Remote Sensing and GIS: A Case Study in and round Rajampet, Kadapa District, Andhra Pradesh, India. Indian Journal of Scientific Research, 8, 123-129.

[18] Loret, E., Martino, L., Fea, M. and Sarti, F. (2015) Combined Remote Sensing and GIS Techniques for Studying the Large Roman Urban System Expansion during the Last Twenty Years. Advances in Remote Sensing, 4, 48-62. http://dx.doi.org/10.4236/ars.2015.41005

[19] Rawat, J.S. and Kumar, M. (2015) Monitoring Land Use/Cover Change Using Remote Sensing and GIS Techniques: A Case Study of Hawalbagh Block, District Almora, Uttarakhand, India. The Egyptian Journal of Remote Sensing and Space Sciences, 18, 77-84. http://dx.doi.org/10.1016/j.ejrs.2015.02.002

[20] Arveti, N., Etikala, B. and Dash, P. (2016) Land Use/Land Cover Analysis Based on Various 
Comprehensive Geospatial Data Sets: A Case Study from Tirupati Area, South India. Advances in Remote Sensing, 5, 73-82. http://dx.doi.org/10.4236/ars.2016.52006

[21] Ledec, G. (1985) The Political Economy of Tropical Deforestation. In: Leonard, H.J., Ed., Diverting Nature's Capital: The Political Economy of Environmental Abuse in the Third World, Holmes and Meier, New York, 179-226.

[22] Contreras-Hermosilla, A. (2000) Center for International Forestry Research. Bogor, Indonesia.

[23] Geist, H.J. and Lambin, E.F. (2002) Proximate Causes and Underlying Driving Forces of Tropical Deforestation. BioScience, 52, 143-150. http://dx.doi.org/10.1641/0006-3568(2002)052[0143:PCAUDF]2.0.CO;2

[24] Anji Reddy, M. (2001) Textbook of Remote Sensing and Geographical Information Systems. BS Publications, Hyderabad.

[25] Jaiswal, R.K., Saxena, R. and Mukherjee, S. (1999) Application of Remote Sensing Technology for Land Use/Land Cover Change Analysis. Journal of the Indian Society of Remote Sensing, 27, 123-128. http://dx.doi.org/10.1007/BF02990808

[26] Selcuk, R., Nisanci, R., Uzun, B., Yalcin, A., Inan, H. and Yomralioglu, T. (2003) Monitoring Land-Use Changes by GIS and Remote Sensing Techniques: Case Study of Trabzon. Proceedings of 2nd FIG Regional Conference, Morocco, 2-5 December 2003, 1-11.

[27] Rogan, J. and Chen, D.M. (2004) Remote Sensing Technology for Mapping and Monitoring Land-Cover and Land Use Change. Progress in Planning, 61, 301-325. http://dx.doi.org/10.1016/S0305-9006(03)00066-7

[28] Anil, N.C., Jai Sankar, G., Jagannadha Rao, M., Prasad, I.V.R.K.V. and Sailaja, U. (2011) Studies on Land Use/Land Cover and Change Detection from Parts of South West Godavari District, A.P-Using Remote Sensing and GIS Techniques. Journal of Indian Geophysical Union, 15, 187-194.

[29] Basu, H. (2007) Geological and Geochemical Aspects of the Gulcheru Formation in the Southwestern Margin of the Cuddapah Basin and Its Potentiality for Uranium Mineralization. Journal of Geological Society of India, 70, 686-688.

[30] Basu, H., Mahendra Kumar, K., Pannerselvam, S. and Chakri, A. (2009) Study of Provenance Characteristics and Depositional History on the Basis of $\mathrm{U}$, Th and $\mathrm{K}$ Abundances in the Gulcheru Formation, Cuddapah Basin in Tummalapalle-Somalollapalle Areas, Cuddapah-Anantapur Districts, Andhra Pradesh. Journal of Geological Society of India, 74, 318328. http://dx.doi.org/10.1007/s12594-009-0136-3

[31] NRSC (2006) NRC-LULC-50K Manual National Land Use Land Cover Mapping Using Multi-Temporal Satellite Data. Remote Sensing and GIS Applications Area National Remote Sensing Centre, Indian Space Research Organisation (ISRO), Department of Space, Government of India, Hyderabad.

[32] Thomas, M.L. and Ralph, W.K. (2000) Remote Sensing and Image Interpretation. John Wiley and Sons Ltd., New York.

[33] Ode, A. and Fry, G. (2006) A Model for Quantifying and Predicting Urban Pressure on Woodland. Landscape and Urban Planning, 77, 17-27. http://dx.doi.org/10.1016/j.landurbplan.2005.01.003

[34] Srimani, P.K. and Prasad, N. (2013) Land Use and Land Cover Mapping by Using Remote Sensing and GIS Techniques-A Case Study of Kasaba Hobli, Hoskote Taluk, Bangalore Rural District, Karnataka, India. International Journal of Engineering Research \& Technol$o g y, 2,2278-0181$.

[35] Brahmabhatt, V.S., Dalwadi, G.B., Chhabra, S.B., Ray, S.S. and Dadhwal, V.K. (2000) Land 
Use/Land Cover Change Mapping in Mahi Canal Command Area, Gujarat, Using MultiTemporal Satellite Data. Journal of the Indian Society of Remote Sensing, 28, 221-232. http://dx.doi.org/10.1007/BF02990813

[36] Anderson, J.R., Hardy, E.E., Roach, J.T. and Witmer, R.E. (1976) Land Use and Land Cover Classification System for Use with Remote Sensor Data. USGS Professional Paper, 964 p.

[37] Saha, S.K., Kudrat, M. and Bhan, S.K. (1990) Digital Processing of Landsat TM Data for Wasteland Mapping in Parts of Aligarh District (Uttar Pradesh), India. International Journal of Remote Sensing, 11, 485-492. http://dx.doi.org/10.1080/01431169008955034

[38] Ghosh, S., Sen, K.K., Rana, U., Rao, K.S. and Saxena, K.G. (1996) Applications of GIS for Land-Use/Land-Cover Change Analysis in a Mountainous Terrain. Journal of the Indian Society of Remote Sensing, 24, 193-202. http://dx.doi.org/10.1007/BF03007332

[39] Gautam, N.C. and Narayanan, L.R.A. (1983) Landsat MSS Data for Land Use/Land Cover Inventory and Mapping: A Case Study of Andhra Pradesh. Journal of Indian Society of Remote Sensing, 11, 15-28.

\section{Submit or recommend next manuscript to SCIRP and we will provide best service for you:}

Accepting pre-submission inquiries through Email, Facebook, LinkedIn, Twitter, etc.

A wide selection of journals (inclusive of 9 subjects, more than 200 journals)

Providing 24-hour high-quality service

User-friendly online submission system

Fair and swift peer-review system

Efficient typesetting and proofreading procedure

Display of the result of downloads and visits, as well as the number of cited articles

Maximum dissemination of your research work

Submit your manuscript at: http://papersubmission.scirp.org/

Or contact ars@scirp.org 